\title{
The Teacher-Training Program in Music at Chautauqua Institution, 1905-1930
}

\author{
EUGENE W. TROTH
}

$\mathrm{M}$ ILlIONS of Americans whose origins are rooted in the small towns and rural areas of the United States remember Chautauqua, the majority of them with vivid nostalgia. Their memory is of the circuit or "traveling" Chautauqua, that phenomenon of American culture organized in 1904 and duplicated to the extent that in 1921 , the year of greatest activity, traveling circuits presented 9,653 programs to an estimated audience of 35 , $500,000 .^{1}$

The circuit Chautauqua was not, however, the original Chautauqua. The original Chautauqua continues to function each summer at its permanent home on Lake Chautauqua, New York. Chautauqua Institution, to give it its official name, was established in 1874. By the beginning of the twentieth century, its activities had made the very word Chautauqua synonymous in the minds of Americans generally with culture, inspiration, education, and the genteel uses of leisure. The original two-week session of the Sunday-school Teachers' Assembly of 1874 had evolved into the six-week summer session of Chautauqua University, offering instruction in schools of language, theology, physical education, journalism, domestic science, pedagogy, expression, arts and crafts, library science, and music. As the result of the efforts and faith of John Heyl Vincent

\footnotetext{
${ }^{1}$ Victoria and Robert O. Case, We Called It Culture (New York: Doubleday \& Company, Inc., 1948), p. 11.
}

and Lewis Miller, the founders of Chautauqua, the institution had exerted by this time a permanent influence upon educational practice through its pioneer efforts in summer study, the extension class, and instruction by correspondence.

Chautauqua evidenced an interest in school music as early as 1875 when Eben Tourjée, founder and director of the New England Conservatory of Music, lectured on the teaching of music in the public schools. That such prominent music teachers as Luther Whiting Mason, T. F. Seward, William Tomlins, and Julia Crane were members of the Chautauqua faculty prior to 1900 indicates a continuing interest. The irregular program of instruction offered by these and other teachers was the forerunner of a Department of Public School Music as a division of the Chautauqua School of Music. Organized in 1905, the department's objective was "to give to all persons interested or engaged in the work of Vocal Music among children, a thorough and complete course of instruction in all branches of Public School Music.",2

Since the vast majority of normal schools, teachers colleges, and universities either did not then support a summer session, or, if so, did not offer instruction in music, the opportunities for securing training of this nature were somewhat limited. Those

\footnotetext{
${ }^{2}$ The Chautauqua Quarterly (July 1905), p.
} 
who desired such training attended the various summer schools sponsored by the publishers of school music books, one of the several widely scattered private training schools (such as the Emma Thomas School in Detroit, Michigan), or received no training whatsoever. Consequently, there existed a decided need for a summer instructional program in school music, and Chautauqua attempted to meet the need with its Department of Public School Music.

The detailed analysis of the teachertraining program may best be organized in relation to the individuals who successively directed departmental activities, as follows: (a) the identification of the respective individual; (b) the curriculum he directed; (c) a reconstruction, when possible, of his beliefs concerning school music; and (d) the significant aspects of his instructional program.

Julia E. Crane, 1905-1906

Julia E. Crane founded the first normal music school in the United States, which exists today as the Crane Music Department of the State University of New York College of Education at Potsdam. As a member of the "Committee of Ten" of the Music Section of the NEA, she helped to formulate in 1903 a statement of the accomplishments in music which might be expected from an elementary school music program. In 1904, she served as a member of the NEA committee whose activity resulted in the first course of study in music for the high school level.

The two courses taught by Crane comprised the core of the teachertraining curriculum (see Table 1) which she organized at Chautauqua. The first, entitled "Methods," outlined a course of study in music for each school grade beginning with the kindergarten and continuing, in 1905, through the grammar school and, in 1906, through the high school. The most appropriate school music materials, many of which were available for examination, were presented and discussed by Crane, and her lectures concerning the techniques of introducing these materials to children were effectively illustrated in her demonstration teaching of classes of Chautauqua children. In the second course, "Song Interpretation," Miss Crane discussed the selection, analysis, and performance of song literature, including as discussion topics such vocal problems as tone quality, enunciation, articulation, intonation, the care and development of the child voice, and the treatment of the voice during mutation.

TABLE 1

Curriculum and Staff of the Chautaugua Department of Public School Music in 1905 AND 1906

\begin{tabular}{|c|c|c|}
\hline \multirow[b]{2}{*}{ Course Title } & \multicolumn{2}{|c|}{ Staff } \\
\hline & 1905 & 1906 \\
\hline $\begin{array}{l}\text { Sight Reading } \\
\text { Methods } \\
\text { Song Interpretation } \\
\text { Conducting } \\
\text { Elementary Theory } \\
\text { Ear Training and Pedagogy } \\
\text { Beginnings of Music and Song Interpretation } \\
\text { Organized Play for Kindergarten and Grades }\end{array}$ & $\begin{array}{l}\text { James Bird } \\
\text { Julia E. Crane } \\
\text { Julia E. Crane } \\
\text { Alfred Hallam } \\
\text { James Bird } \\
\text { Carrie Alchin }\end{array}$ & $\begin{array}{l}\text { James Bird } \\
\text { Julia E. Crane } \\
\text { Julia E. Crane } \\
\text { Alfred Hallam } \\
\\
\text { Mari R. Hofer } \\
\text { Mari R. Hofer }\end{array}$ \\
\hline
\end{tabular}


No more specific indication of the scope of Crane's beliefs concerning the training of the music teacher is available than in the following excerpt from an address which she delivered to the Music Teachers National Association:

The teacher or supervisor of school music must today be a musician of no mean attainments; he must sing well, understand the care of the voice, play the piano, and understand the orchestral instruments sufficiently to be able to conduct a high school orchestra. He must understand the history and theory of music, for many high schools are offering elective courses in these subjects. But this is not all. He must know schools, and their possibilities and limitations; he must be well versed in the pedagogical literature of the day and must know the most approved methods of teaching, not to be able to teach other subjects, but because the grade teachers will make far better use of his plans and instructions if he can illustrate with methods of teaching with which they are familiar. Then he must know how to manage large classes; in other words, he must be the most successful disciplinarian in the school. His relationship to the superintendent of schools is a different one from that of the grade teachers, and he must know his place as the director, advisor, and friend of the grade teacher and at the same time to be the able assistant of the superintendent. It will be his province to instruct not only the pupils, but the teachers, the superintendent, the board of education, and the public. ${ }^{3}$

Many of the principles advocated and practiced by Julia Crane have been assimilated into contemporary philosophies of teacher training, the most notable of which is undoubtedly the student teaching experience. Moreover, her psychological approach to learning-a sequence of aural, oral, physical, and visual experience-is as pedagogically

3Julia E. Crane, "The Relation of the Professional Musician to School Music," MTNA Proceedings, 1912, p. 105. sound today as it was in the early twentieth century.

$$
\text { Alfred Hallam, } 1907
$$

Advance advertising material describing the Chautauqua summer session of 1907 indicated that Julia Crane would continue to direct the activities of the Department of Public School Music. However, she did not return, and Alfred Hallam, director of the Chautauqua School of Music, assumed this responsibility.

\section{TABLE 2}

Curriculum and Staff of The Chautauqua Department of Public School Music IN 1907

\begin{tabular}{l|l}
\hline \hline \multicolumn{1}{c|}{ Course Title } & \multicolumn{1}{c}{ Staff } \\
\hline Elementary Theory and & James Bird \\
Harmony & \\
Methods and Course of & \\
Study from the Kinder- & \\
garten through the Pri- & \\
mary Grades & Lovira Tait \\
Methods and Course of & \\
Study from the Primary & \\
Grades through Grammar & Frank Croxton \\
School & Alfred Hallam \\
High School Music and & \\
Conducting & \\
\hline
\end{tabular}

The course offerings which he hurriedly arranged (see Table 2) were taught by staff members in other departments of the School of Music. Due to this fact, the offerings were in all probability mediocre with one exception. Hallam, supervisor of music for the public schools of Mount Vernon, New York, introduced a course in "High School Music" which may have reflected some aspects of the high school music curriculum which Osborne McConathy had inaugurated the previous year in Chelsea, Massachusetts. At any rate, to limit specifically the content of a course offering to the high school level was indicative of Chautauqua's 
TABLE 3

Curriculum and Staff of the Chautauqua Department of Public School Music from 1908 Through 1910

\begin{tabular}{l|l|l|l}
\hline \hline \multicolumn{1}{c|}{ Course Title } & \multicolumn{3}{|c}{ Staff } \\
\cline { 2 - 4 } & \multicolumn{1}{c|}{1908} & 1909 & 1910 \\
\cline { 2 - 4 } & Staff & Staff & Staff \\
Staff Lectures & Cogswell & Cogswell & Cogswell \\
Methods & Cogswell & Cogswell & Cogswell \\
Public School Music & Cogswell & Cogswell \\
Ear Training & Bird & Bird & Bird \\
Elementary Harmony & Cogswell & Cogswell & Cogswell \\
Orchestration and Conducting & Bird & Bird & Bird \\
Advanced Harmony & Guest Staff & & Bird \\
Illustrative Methods & & Tobey \\
Solfeggio and Sight Singing & & & Tobey \\
Music Analysis & & & \\
Piano Normal & & &
\end{tabular}

awareness of contemporary trends in school practice and of its attempt to offer a training program geared to provide adequately prepared teachers.

Hamlin E. Cogswell, 1908-1910

Hamlin E. Cogswell of the State Normal School in Indiana, Pennsylvania, directed the Department of Public School Music at Chautauqua from 1908 through 1910. As president of the Music Section of the NEA, Cogswell had signed the letter which appeared in School Music Monthly inviting music supervisors to attend a regional meeting in Keokuk, Iowa, in April of 1907. Cogswell was to have presided at this meeting which marked the beginning of the Music Educators National Conference; had illness not prevented his attending, he might have been elected the first president of the organization.

The curriculum which Cogswell organized at Chautauqua is indicated in Table 3. Although not obvious from the tabulation, two courses of studyone for music supervisors and one for classroom teachers-were offered. A significant requirement of both programs, the "Illustrative Methods," was an attempt by Cogswell to broaden what he considered to be a somewhat limited approach to school music that characterized the various summer schools sponsored by the publishers of school materials. His avowed purpose was to acquaint and to inform music supervisors and teachers with all systems, methods, and materials. To achieve this goal he arranged for several prominent teachers, supervisors, and representatives of the major book companies to lecture at Chautauqua. That Cogswell succeeded in his purpose is verified in a report of the project which Philip Hayden wrote in School Music Monthly.

Of especial significance in the curriculum was the course in "Orchestration and Conducting" in which Cogswell discussed the instruments of the orchestra, the possibilities of instrumentation, and arranging materials for school use. This was actually a course in instrumental methods. Never before had instruction of this nature been offered at Chautauqua, and it is considered by the writer to be an early example of a specific training for instrumental school music.

Albert E. Brown 1911-1912

In 1911 and 1912, Albert E. Brown of the State Normal School in Lowell, 


\section{TABLE 4}

Curriculum and Staff of the Chautauqua Department of PUblic SchoOl MuSIC FROM 1911 ThroUgh 1912

\begin{tabular}{|c|c|c|}
\hline \multirow[b]{2}{*}{ Course Title } & \multicolumn{2}{|c|}{ Staff } \\
\hline & 1911 & 1912 \\
\hline $\begin{array}{l}\text { Methods for Supervisors } \\
\text { a. Subject matter and Methodology } \\
\text { b. Course of study } \\
\text { c. Melody writing } \\
\text { d. Pedagogy } \\
\text { 1. Musical conceptions } \\
\text { 2. Sight singing } \\
\text { 3. Voice training } \\
\text { 4. Musical interpretation } \\
\text { Methods for Grade Teacher } \\
\text { a. Sight reading } \\
\text { b. Ear training } \\
\text { c. Methodology }\end{array}$ & Brown and Bird & Brown and Bird \\
\hline
\end{tabular}

Massachusetts, directed the Chautauqua teacher training program in music. Brown specifically defined in the curriculum (see Table 4) training programs for both the music supervisor and the classroom teacher.

What appears to have been a reduction in course offerings was due to the fact that those courses primarily concerned with the theoretical aspects of music in previous summers were incorporated into a Department of Music Theory beginning in 1911. Brown organized the "Methods for Supervisors" into a concentrated three-week course meeting four hours each day and repeated the course in the latter half of the summer session. The "Methods for the Grade Teacher" met daily throughout the entire six-week session.

TABLE 5

Curriculum and Staff of the Chautauqua Department of Public School Music From 1913 Through 1915

\begin{tabular}{|c|c|c|c|c|}
\hline \multirow[b]{2}{*}{ Course Title } & \multicolumn{4}{|c|}{ Staff } \\
\hline & 1913 & 1914 & 1915 & 1916 \\
\hline $\begin{array}{l}\text { Methods for Supervisors } \\
\text { a. Music Fundamentals } \\
\text { b. Music History, Form, and } \\
\text { Orchestration } \\
\text { c. Elementary Harmony } \\
\text { d. Conducting }\end{array}$ & & Hawley & Hawley & Hawley \\
\hline $\begin{array}{l}\text { Methods for Supervisors } \\
\text { a. Methods and Materials } \\
\text { b. Graded Course of Study } \\
\text { c. Melodic Writing and } \\
\text { Sight Singing } \\
\text { d. Voice Culture and Song } \\
\text { Interpretation } \\
\text { General Course for High School } \\
\text { Teachers }\end{array}$ & Hawley & Hawley & Hawley & Hawley \\
\hline $\begin{array}{l}\text { Methods for Grade Teachers } \\
\text { Fundamentals of Music } \\
\text { Sight Reading }\end{array}$ & $\begin{array}{l}\text { Bird } \\
\text { Bird }\end{array}$ & $\begin{array}{l}\text { Bird } \\
\text { Bird }\end{array}$ & $\begin{array}{l}\text { Bird } \\
\text { Bird }\end{array}$ & $\begin{array}{l}\text { Bird } \\
\text { Bird }\end{array}$ \\
\hline
\end{tabular}


Available data indicate that Brown, primarily a singing teacher, emphasized vocal production and song interpretation to a considerable degree, in all probability with slight reference to the school situation. Subsequent to his two summers spent at Chautauqua, he concentrated largely on the teaching of voice in the private studio. In 1917, Brown was elected the first president of the Eastern Supervisors Conference.

\section{Edward R. Hawley, 1913-1916}

Edward R. Hawley of the State Normal School in Westfield, Massachusetts, succeeded Brown as director of the Chautauqua training program. Analysis of Hawley's initial curriculum (see Table 5) indicates no change from the former program. In 1914, however, he inaugurated a sequence of course offerings for the music supervisor, each course a concentrated one of three weeks' duration. Thus, both courses in the sequence could be elected during the same summer session.

The first course included the fundamentals of music, some study of music literature and harmony as applicable to the high school teaching situation, and conducting. Such course content indicates that Hawley was well acquainted with the expanded scope of the high school curriculum in music. The second course of the sequence was concerned solely with problems of the elementary school-courses of study, music reading, materials, and the care of the child voice.

That Hawley insisted upon a prerequisite of general musical knowledge and skill prior to student election of methods courses is especially significant. Moreover, the definitive demarcation between teacher preparation for the elementary school and for the high school is clearly indicative of the growing im- portance being attached to the secondary school music program.

In 1914, Chautauqua announced a plan to assist students in securing credit for courses completed at Chautauqua in regularly accredited universities and colleges. For the first time the institution indicated its awareness of the problems likely to arise in the area of teacher certification.

\section{Howard C. Davis, 1917-1924}

Howard C. Davis, supervisor of music in Chelsea, Massachusetts, joined the Chautuaqua faculty in 1917 as director of the teacher-training program in music. Largely through his efforts, the Eastern Supervisors Conference had been organized that year, and he served as president of the organization in 1920 .

Although Davis effected no curricular changes in 1917, in the following year he extended the curriculum to encompass a three-year program, functioning within the framework of a Department of School and Theoretical Music (see Table 6). Any of the thirteen courses offered might be passed by demonstration of proficiency, thus making it possible to complete the prescribed program in less than the three summers otherwise required. A certificate was issued to the student for each course completed, while a diploma designating him as supervisor of music was granted at the completion of the three-year program.

That Davis considered the well trained teacher to be both musician and pedagogue is apparent in the breadth of the curriculum which he organized. Specific courses in practice teaching, supervision and administration, methods of teaching harmony, and the teaching of violin in class were offered for the first time, clearly indicative of the diversity of the rapidly growing 
TABLE 6

Curriculum and Staff of the Chautauqua Department of SchoOl and TheORETICAL Music From 1917 Through 1919

\begin{tabular}{|c|c|c|c|}
\hline \multirow[b]{2}{*}{ Course Title } & \multicolumn{3}{|c|}{ Staff } \\
\hline & 1917 & 1918 & 1919 \\
\hline $\begin{array}{l}\text { Course for Supervisors } \\
\text { High School Music } \\
\text { Course for Grade Teachers } \\
\text { Sight Reading } \\
\text { First Year } \\
\text { Music Fundamentals } \\
\text { Practice Teaching } \\
\text { Choral Conducting } \\
\text { Dictation and Melody Writing } \\
\text { Elementary Harmony } \\
\text { Music Appreciation I } \\
\text { Child Voice } \\
\text { Second and Third Years } \\
\text { Advanced Harmony } \\
\text { Music Appreciation II } \\
\text { Methods of Teaching Harmony } \\
\text { Class Method for Teaching Violin in School } \\
\text { Organization and Administration }\end{array}$ & $\begin{array}{l}\text { Davis } \\
\text { Davis } \\
\text { Bird } \\
\text { Bird }\end{array}$ & $\begin{array}{l}\text { Bird } \\
\text { Bird } \\
\text { Davis } \\
\text { Davis } \\
\text { Davis } \\
\text { Rebmann } \\
\text { Rebmann } \\
\text { Rebmann } \\
\text { Davis } \\
\text { Rebmann } \\
\text { Rebmann } \\
\text { Rebmann } \\
\text { Rebmann } \\
\text { Davis }\end{array}$ & $\begin{array}{l}\text { Bird } \\
\text { Davis } \\
\text { Davis } \\
\text { Davis } \\
\text { Borgwald } \\
\text { Borgwald } \\
\text { Borgwald } \\
\text { Davis } \\
\text { (?) Borgwald } \\
\text { (?) Borgwald } \\
\text { (?) Borgwald } \\
\text { (?) Borgwald } \\
\text { Davis }\end{array}$ \\
\hline
\end{tabular}

school music program. Due to this breadth of instruction, Davis' threeyear program was the initial Chautauqua training program in any subject area to be recognized officially by the Board of Regents of the State of New York, which agreed to accept Chautauqua credit toward teacher certification on an equal basis with that of any approved university or college summer session.

The efforts of Davis to improve instruction resulted in an increased registration of 1200 per cent between 1917 and 1920. Not content with the status quo, Davis again revised the curriculum in 1920, increasing the total course offerings to twenty-five and arranging them in a four-year program (see Table 7). Those who studied for the diploma were expected to demonstrate an agreeable singing voice and a proficiency at the piano; if the diploma were in instrumental music, a facility on one orchestral instrument was required before admission, and a working knowl- edge of at least three was to be mastered during the training period.

The growing emphasis on professional education, influenced no doubt by teacher certification codes, was reflected in courses in educational psychology, child psychology, history of education, and principles of teaching. In addition to increasing the requirements in music theory and music literature, Davis supplemented the teaching preparation with courses in class piano, class instrumental methods, instrumentation, and orchestration.

That Chautauqua was beginning to feel the pressure of university and college training programs in music is hinted in the following remarks of Davis in The Musician:

Much of the function of the summer school is now being met by the college and it may be that soon the bulk of the training of supervisors will be done in the winter. It is frequently said that it cannot be properly done in the short time at the disposal of the summer school. This is not so. The courses of 
TABLE 7

Curriculum and Staff of the Chautauqua Department of School and Theoretical Music from 1920 Through 1924

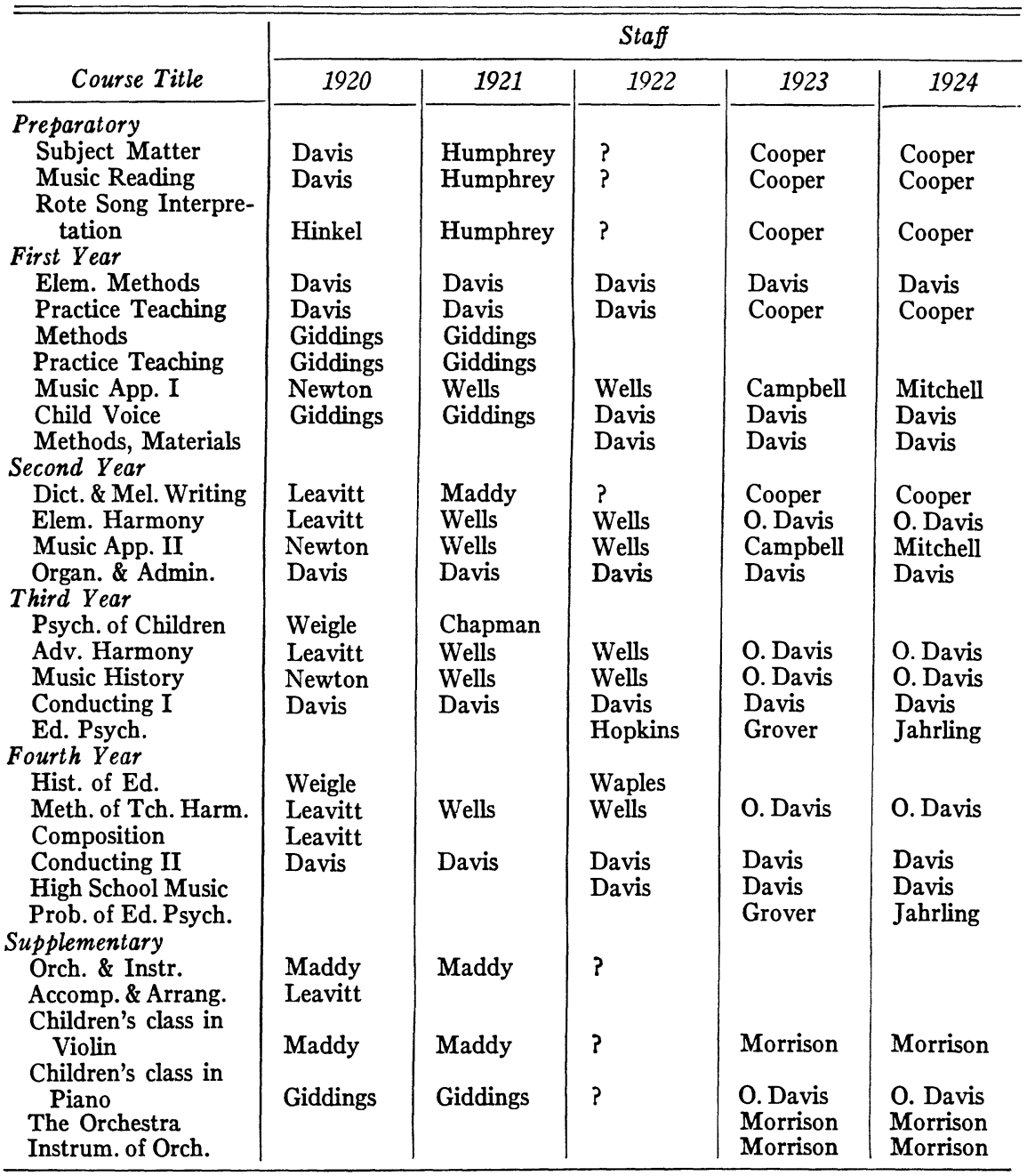

the best summer schools are so arranged as to allow the most intensive work and the only argument which may truthfully be advanced against them is that there may be more extended time for practice teaching in the winter months. 4

"Howard C. Davis, "The Summer School and the Music Supervisor," The Musician, XXVIII (September 1923), 24.
Robert L. Osburn, 1925-1930

In 1923, arrangements were completed between Chautauqua Institution and New York University whereby the university supervised and administered the Chautauqua program in professional education, the result being that Chautauqua students earned resident univer- 
TABLE 8

Curriculum and Staff of the Chautauqua Department of PUblic School MUSic From 1925 ThroUgh 1930

\begin{tabular}{|c|c|c|c|c|c|c|}
\hline \multirow[b]{2}{*}{ Course Title } & \multicolumn{6}{|c|}{ Staff } \\
\hline & 1925 & 1926 & 1927 & 1928 & 1929 & 1930 \\
\hline $\begin{array}{l}\text { Elementary Theory } \\
\text { Prep. Sight Reading } \\
\text { Prep. Dictation } \\
\text { Sight Reading A } \\
\text { Sight Reading B } \\
\text { Sight Reading C } \\
\text { Dictation A } \\
\text { Dictation B } \\
\text { Dictation C } \\
\text { Harmony A } \\
\text { Harmony B } \\
\text { Tch. of Music (Lower) } \\
\text { Tch. of Music (Upper) } \\
\text { Tch. of Music } \\
\text { (Jr., Sr. High) } \\
\text { Prac. Tch. and } \\
\text { Observation } \\
\text { Conducting } \\
\text { School Orch. and Band } \\
\text { Class Piano Methods }\end{array}$ & $\begin{array}{l}\text { Heinemann } \\
\text { Osburn } \\
\text { Osburn } \\
\text { Heinemann } \\
\text { Osburn } \\
\text { Osburn }\end{array}$ & $\begin{array}{l}\text { Heinemann } \\
\text { Osburn } \\
\text { Heinemann } \\
\text { Morgan } \\
\text { Morgan } \\
\text { Morgan } \\
\text { Heinemann } \\
\text { Heinemann } \\
\text { Osburn } \\
\text { Heinemann } \\
\text { Osburn } \\
\text { Osburn }\end{array}$ & $\begin{array}{l}\text { Jones } \\
\text { Heinemann } \\
\text { Osburn } \\
\text { Jones } \\
\text { Jones } \\
\text { Jones } \\
\text { Morgan } \\
\text { Morgan } \\
\text { Heinemann } \\
\text { Heinemann } \\
\text { Osburn } \\
\text { Heinemann } \\
\text { Osburn } \\
\text { Osburn }\end{array}$ & $\begin{array}{l}\text { Jones } \\
\text { Jones } \\
\text { Heinemann } \\
\text { Jones } \\
\text { Heinemann } \\
\text { Young } \\
\text { Jones } \\
\text { Jones } \\
\text { Young } \\
\text { Young } \\
\text { Young } \\
\text { Heinemann } \\
\text { Heinemann } \\
\text { Osburn } \\
\text { Heinemann } \\
\text { Osburn } \\
\text { Osburn } \\
\text { Young }\end{array}$ & $\begin{array}{l}\text { Vogt } \\
\text { Vogt } \\
\text { Waller } \\
\text { Jones } \\
\text { Jones } \\
\text { Jones } \\
\text { Waller } \\
\text { Jones } \\
\text { Waller } \\
\text { Waller } \\
\text { Osburn } \\
\text { Osburn }\end{array}$ & $\begin{array}{l}\text { Vogt } \\
\text { Vogt } \\
\text { Vogt } \\
\text { Waller } \\
\text { Jones } \\
\text { Vogt } \\
\text { Jones } \\
\text { Jones } \\
\text { Waller } \\
\text { Jones } \\
\text { Waller } \\
\text { Waller } \\
\text { Osburn } \\
\text { Osburn } \\
\text { Woods }\end{array}$ \\
\hline
\end{tabular}

sity credit for the work completed. Similar arrangements with the Chautauqua Department of Public School Music were completed in 1925, and Hollis Dann, head of the university music department, headed the Chautauqua department in a non-resident capacity. Robert L. Osburn served as the resident director, although Dann assumed the responsibility for the selection of course offerings and staff members.

The content of those courses offered at Chautauqua (see Table 8) imitated exactly that of similar courses on the university campus, and the credit earned was applicable to a university degree. According to university regulations, a high school diploma was a prerequisite for registration, although those not meeting the requirement were allowed to register as special students.

Approximately one-half of the curriculum concentrated on basic musical skills, quite in keeping with Dann's belief that "fundamental musicianship is indispensable to the music educator." Instruction in teaching methods, observation and practice teaching, conducting, and one course in instrumental methods completed the course offerings. In most instances, text books of Dann were used and, since the material was presented by his students, there is no doubt that Dann's personal philosophies dominated all instruction.

\section{Summary}

Although the teacher-training program in music continued at Chautauqua after 1930, its importance and influence diminished. In recent years, short term courses of a workshop nature have comprised its infrequent offerings. Just as the growth of the Chautauqua program reflected concurrent trends in school music, so its decline paralleled certain developments in teacher training: (1) the increased standardization of teacher certification

\footnotetext{
${ }^{5}$ Reven S. DeJarnette, Hollis Dann: His Life and Contribution to Music Education (Boston: C. C. Birchard Company, 1940), p. 62 .
} 
TABLE 9

A Chronology of Course Offerings Between 1905 and 1930

\begin{tabular}{|c|c|c|c|c|c|c|}
\hline Department Head & Year & $\begin{array}{c}\text { Total } \\
\text { Courses }\end{array}$ & $\left|\begin{array}{c}\text { Music } \\
\text { Education }\end{array}\right|$ & $\begin{array}{l}\text { Music } \\
\text { Theory }\end{array}$ & $\left|\begin{array}{c}\text { Music } \\
\text { Literature }\end{array}\right|$ & Others \\
\hline Julia Crane & $\begin{array}{l}1905 \\
1906\end{array}$ & $\begin{array}{l}6 \\
6\end{array}$ & $\begin{array}{l}3 \\
5\end{array}$ & $\begin{array}{l}3 \\
1\end{array}$ & & \\
\hline Alfred Hallam & 1907 & 4 & 3 & 1 & & \\
\hline Hamlin Cogswell & $\begin{array}{l}1908 \\
1909 \\
1910\end{array}$ & $\begin{array}{r}7 \\
7 \\
10\end{array}$ & $\begin{array}{l}3 \\
3 \\
3\end{array}$ & $\begin{array}{l}3 \\
3 \\
4\end{array}$ & & $\begin{array}{l}1 \\
1 \\
3\end{array}$ \\
\hline Albert Brown & $\begin{array}{l}1911 \\
1912\end{array}$ & $\begin{array}{l}2 \\
2\end{array}$ & $\begin{array}{l}2 \\
2\end{array}$ & & & \\
\hline Edward Hawley & $\begin{array}{l}1913 \\
1914 \\
1915 \\
1916\end{array}$ & $\begin{array}{l}4 \\
4 \\
4 \\
4\end{array}$ & $\begin{array}{l}3 \\
3 \\
3 \\
3\end{array}$ & $\begin{array}{l}1 \\
1 \\
1 \\
1\end{array}$ & & \\
\hline Howard Davis & $\begin{array}{l}1917 \\
1918 \\
1919 \\
1920 \\
1921 \\
1922 \\
1923 \\
1924\end{array}$ & $\begin{array}{l}4 \\
15 \\
14 \\
25 \\
22 \\
16+ \\
24 \\
24\end{array}$ & $\begin{array}{c}3 \\
7 \\
6 \\
14 \\
13 \\
10+ \\
15 \\
15\end{array}$ & $\begin{array}{l}1 \\
6 \\
6 \\
8 \\
6 \\
3+ \\
6 \\
6\end{array}$ & $\begin{array}{l}2 \\
2 \\
3 \\
3 \\
3 \\
3 \\
3\end{array}$ & \\
\hline Robert Osburn & $\begin{array}{l}1925 \\
1926 \\
1927 \\
1928 \\
1929 \\
1930\end{array}$ & $\begin{array}{l}10 \\
13 \\
16 \\
19 \\
13 \\
16\end{array}$ & $\begin{array}{l}6 \\
6 \\
6 \\
7 \\
6 \\
7\end{array}$ & $\begin{array}{r}4 \\
6 \\
9 \\
11 \\
6 \\
8\end{array}$ & $\begin{array}{l}1 \\
1 \\
1 \\
1 \\
1\end{array}$ & \\
\hline
\end{tabular}

codes which motivated attendance at regularly accredited academic institutions; and (2) the increased number of summer sessions in normal schools, teachers colleges, and universities which offered teacher-training programs in music.

The attitude of Chautauqua Institution to such developments was effectively stated by Arthur E. Bestor, president of the institution from 1915 through 1944, in the following remarks concerning all phases of education:

It [Chautauqua] is a pioneer in educational development. It was the first summer school in the country established at a time when conventional institutions held that it was impossible for people to study in the vacation. ... It gave the initial impulse and opportunity to many movements which are carrying on their own work under their own name. It withdraws from fields when other institutions are developed which can do specific work in a more effective way. ${ }^{6}$

Certainly there has been no Chautauqua endeavor to which these words are more applicable than to its training program in music. ${ }^{7}$

\section{University of Michigan}

'Chautauqua Institution, President's Report, 1923 , p. 13.

${ }^{7}$ This paper was read at the meeting of the North Central Division of the Music Educators National Conference in Chicago, 1959, and is based upon information contained in the author's doctoral dissertation of the same title (University of Michigan, 1958). 